\title{
The Fading Existence Of Javanese Ethical Value As A Student's Lifestyle (Case Of : Junior High School In North Semarang)
}

\author{
Elly Kismini ${ }^{1}$, Tri Marhaeni Pudji Astuti ${ }^{2}$, Maman Rachman ${ }^{3}$ and Muhammad Jazuli \\ ellykismini@yahoo.co.id ${ }^{1}$, trimarhaenipudjiastuti@mail.unnes.ac.id ${ }^{2}$, marachman102@yahoo.com³ \\ Doctoral Program, Department of Social Science Education PPS Universitas Negeri Semarang, \\ Jl. Kelud Utara III, Semarang 50237 Indonesia 1,2,3
}

\begin{abstract}
Javanese society has a high value culture, including the life principle in the form of Javanese ethical values. This value needs to be applied to lifestyle as a manifestation of the preservation of local culture in order to counteract the negative effects of modernization and globalization. This paper is based on the results of research conducted at Public and Private Middle Schools in the North Semarang region in 2018. The purpose of this paper is to provide an overview of the fading existence of Javanese ethical values as a lifestyle among middle school students in North Semarang. The method used in this research is qualitative method. Data collection techniques used in the study: observation, in-depth interviews and documentation. In testing the validity of the data using triangulation techniques. Data analysis uses qualitative data analysis interactively with stages: data collection, data reduction, data presentation, conclusions or verification. The results of the study show that Javanese ethical values in the form of principles of harmony and respect have experienced fading caused by various factors. The conclusion has been a cultural change in lifestyle among middle school students in North Semarang.
\end{abstract}

Keywords: fading, existence, Javanese ethical values, lifestyle, junior school students

\section{Introduction}

Indonesia is a great nation, because it consists of various ethnic groups with high value cultural and attached to each of its ethnic groups that need to be preserved and passed on to future generations. One of the cultural heritages that needs to be preserved in the life of Javanese people as part of the Indonesian nation is Javanese ethical values. In the Javanese tradition, everyone feels obliged to create harmony and social harmony or if harmony and social harmony have existed, then everyone is obliged to maintain it. There are two principles that are considered by the Javanese before acting or responding to something, namely the principle of harmony and the principle of respect. Pillars aim to maintain harmony. "Rukun" (Harmony) means being in a state of harmony, calm and calm without disputes and conflicts. The principle of respect states that humans in speaking and carrying themselves always show respect for others according to their degree and position[1]. Globalization and modernization have changed the values that exist in the local community, as well as the values of Javanese ethics as a lifestyle have undergone many shifts due to the progress of the times and supported by technological developments. In the theory of cultural change, Geertz says that cultural change takes place in accordance with the passage of time and the plurality of sociocultural realities faced by its supporters [2]. In the 
concept of Ki Hadjar Dewantara, educational institutions are social institutions that determine the progress and civilization of the nation. As a formal institution the school has a function related to the conservation of regional cultural values [3].School as an institution that functions as a means of maintaining social order and social control in reality is not always successful, as evidenced by the many deviations made by students. One level of education that plays a role in preserving Javanese ethical values is the level of junior high school education, this is caused because the age of middle school students is generally classified as the teenage age[4]. One characteristic of adolescence is the growing understanding of moral concepts and values. Middle school students as a social group, of course, have a specific lifestyle when compared to other social groups, especially the location of schools located in areas that have heterogeneous characteristics of the community, such as what happened in North Semarang. In this region there are also many occupants occupied by ethnic Chinese . Lifestyle is always related to efforts to make oneself exist in certain ways and different from other groups[5]. Lifestyle is an active adaptation of individuals to social conditions in order to meet the need to unite and socialize with others[6]. Javanese ethical values need to be applied as a lifestyle. As stated by Audifax in Adlin that: lifestyle is necessary local forms of knowledge because they always get special identities through certain contexts of an established way of life [7]. This is why when opportunities are available for the emergence of models of local knowledge that can be used as reference references for lifestyle[8]-[13].

\section{Methods}

The type of research used in this study is qualitative research. While the approach used in this study is a phenomenological approach. Focus of this study are : Javanese ethics lifestyle junior high school students in North Semarang. This research devide into two data, namely: primary data and secondary data . Primary data obtained from subjects and research informants. The research subjects were students in Semarang State Middle School 25 and students at Theresiana Tanah Mas Middle School Semarang. Secondary data is obtained from various reading sources and various other sources that are relevant to the topic of research, scientific work, internet journal articles and the results of previous studies that relate to the focus of the study under study. Data collection techniques in the form of observation, interviews and documentation. In testing the validity of the data this study uses triangulation techniques. In this study using a qualitative analysis description technique .

According to Miles and Haberman that activities in qualitative data analysis do it interactive and takes place continuously until complete[14]. Technique this analysis is carried out by stages (1) data collection, (2) data reduction, (3) presentation of data, (4) conclusions or verification.

\section{Results and Discussion}

In Javanese society there are two most decisive principles in every human being, namely the principle of harmony and respect. These two principles have experienced a shift in the lives of middle school students in North Semarang. 


\subsection{Fading Value Pillars}

The value of harmony as a lifestyle has shifted to middle school students in North Semarang, this can be seen from the case of some students engaged in fights both individual and group in the form of brawls with other schools, as had been done by SMP Negeri 25 students involved in brawls with students from one of the private junior high schools in North Semarang. In the brawl there is a term used, namely the term "birthday" which means revenge brawls, and the term "silahturahmi" which means brawl invades other schools. As expressed by informants that students who engage in brawls or fights are only a small part, while most of the children here are fine. sometimes there are people who are taken away by the police but are not afraid because they feel they have a mass. Sometimes fights begin with problems in the place of residence, because in general the student's friends at school are also friends in the neighborhood. Teen fights are a form of delinquency that cannot be tolerated either individually or in groups. A fight is a deviation from harmony in Javanese ethics. The existence of the Javanese depends on its unit with the group. Opposing the will of others directly or showing hostility is very contrary to his feelings. Therefore, any behavior that deviates from the principle of harmony will be faced with strong psychological resistance. An irregular atmosphere, which is not aligned, quarrels with loud voices, all disturbance towards calm and social balance is very hated [1]. The word rukun refers to the way of acting. Being harmonious means removing signs of tension in society or between individuals so that social relations still look harmonious and $\operatorname{good}[1]$.

\subsection{Fading Respect Value}

In a Java ethical value of respect which consists of a sense isin (shame). wedi (fear) and sungkan (hesitate)

Isin (Shame). Fear of the sense isin (shame) in the ethics of Java is one of the strongest motivations for the Javanese to adjust the behavior with societal norms. While Gunarsa suggests that feelings of shame are anxieties experienced by someone towards the views of others towards him[1]. Shame usually occurs in social relations more related to how I am seen by others. To grow a culture of isin (shame) among students. Theresiana Tanah Mas Junior High School made an appeal in the form of posters mounted on the classroom walls so that they could be seen by all students. As for SMP 25 implementing rules and regulations of learners, as well as a mop shape nggaran and sanctions. Shame culture were applied in SMP Theresiana synonymous with violations and sanctions in the category of mild and moderate, so that sanctions against soft light prevailing in SMP 25. The presence of the discipline and sanctions in the light category showed low shame on themselves were a man. this can be seen from several behaviors including:

Come To School Late. Some students of SMP Negeri 25, often students arrive late at school for various reasons including being stuck in traffic on the trip. The road to the school through the streets Kokrosono, of which there are railway crossings is causing a traffic jam, if there is a train pass by. There are also students who are late because they wake up late. This is different from the condition of Theresiana Tanah Mas Junior High School students. Rarely is there anything wrong. If there are students who are often late for the same reason their parents are usually called. 
Breaking The Rules. Some students often wear wrong uniform, eg : they should wear batik SMPN 25, but there are students who wear blue and white ( Student Council ). Wear non-black shoes that should be black plain for every day, except Thursday students are freed wearing shoes not black, to give them the freedom to wear if they have other shoes they have. Sometimes there are students who jump the fence when going to class, because they feel incomplete attributes that are used. Other violations were carried out by repeated work with friends, lessons at the canteen, wearing socks that did not have the logo of SMP Negeri 25, not taking midnight prayers in congregation, even running and being chased by teachers, being late for school because of waking up late, fighting because of friendship , not doing homework told to run in the field, changing clothes instead of snacks, told to push up , crowded in class. This is different from what happened at Theresiana Tanah Mas Junior High School Semarang . violations of the uniform usually does not wear a belt to male students laki.biasanya disur $\mathrm{u} t \mathrm{~h}$ to the right or the teacher to take the plastic rope and obedient student (according to). But the next day I was cured.

Speaking Disrespectful to Friend. From the observations of the researchers also found male students joking with their friends using the word tai (dirt) and asu (dog) to express dislike even in a joking contest. Similarly, this condition occurs in students of Middle Theresiana Tanah Mas. From the available data it appears that a Java ethics value associated with isin (shame) at some junior high school students in North Semarang. Students carry out several violations which are included in the Javanese ethics category must be avoided, because if someone commits the violation the person will feel isin (ashamed). Shame in essence is closely related to human needs to cover what is revealed. Feeling embarrassed means that it is seen by others. Shame is present when someone is evaluated by the closest environment and in that assessment someone feels that they do not display self-standards and ideal values in their environment . Gilbert and Irons (2009) emphasize that emotion of shame is associated with the frequent emergence of selfevaluation when the social environment is in conflict with the behavior displayed, related to limited Results and Discussion. Resources and related to the inadequacy of mutual supportive and caring behavior among members of social groups. Javanese people usually do not appear to be disturbed by all kinds of rules of courtesy, but appear more relaxed in that framework. Fearness about isin (shame) is one of the strongest motivations for the Javanese to adjust his behavior to the norms of society [1]. Violations of regulations that should have caused isin (shame) were carried out as a lifestyle by several junior high school students in North Semarang. Lifestyle is seen as behavioral patterns expressed by humans in response to life and everything that surrounds it[7]. Meanwhile, lifestyles are patterns of action which distinguishes between a one person to another [1].

Wedi (Fear). Wedi means fear, both as a reaction to physical threats and as a fear of the consequences of unpleasant actions [1]. Wedi can also be interpreted as fear of people who are respected. The fading of the feeling of wedi (fear), can be seen from the forms of violations with severe sanctions categories, such as:

Saying dirty or behaving inappropriately towards the teacher. Schools apply regulations to always do 5S ( smile, greetings, greetings, courtesy and courtesy) for Junior High School 25, while Theresiana Tanah Mas Junior High School 3S (smile, greetings and greetings) . It aims to train students to respect others, both older and younger, especially to the older ones, namely the teacher at the school. If the teacher asks the Java language, the Java language also will answer "ngoko". Sometimes there are students who talk to the teacher with a bad attitude such as talking while leaning back. Students of SMPN 25 too many did not polite, thanked when 
receiving a gift from someone else, be it teachers and school friends. While the students of Middle School Theresiana according to the informants of the students at this school are accustomed to saying excuse and thank you. Javanese consists of two different levels in words and grammar. One manuscript language expresses respect, while the other expresses intimacy named "ngoko", then the third language level is "kromo inggil", closely related to the person and expresses very high respect. First of all the child must feel wedi towards the person who must be respected. Krama language is used as a communication tool if there are differences in status or age. Manners language used in conversation people who have status or age was lower against higher. While the ngoko language is used as a communication tool if the interaction is parallel both in terms of status and age. In communicating humans in addition to using language as a means of communication, symbols are also used in the form of gestures that show the expressions or attitudes of people who are interacting. In the Java community are taught that a child's posture when communicating with older learners should be the attitude of k's down the face, as a form of respect for the people with whom communication. So if students who communicate with their backs and with a face that looks upward, show that there is an attitude of disrespect towards the person they are talking to in this case is the teacher whose age and status are above students.

Leaving Lessons Without Permission Or Skipping Lessons. Students at Semarang State Junior High School School 25 have a character when skipping using the term pull out and done in various ways including: some students who run away from the class by jumping on the high fence of the school. Though the fence wall is equipped with sharp iron wire. The wire was damaged using wood near the fence. Unlike the Theresiana Tanah Mas Junior High School students there have never been cases of students who fled the class (pull out), especially by jumping the fence. This is because the number of students is small so students are afraid of taking actions that are in violation because they can be easily seen by the teacher.

Smoking In School. Students of SMPN 25 a da few students who are often caught with cigarettes or smoke. Generally, these students smoked in the lavatory or in the corners of the school. But only a few students are often caught smoking. Students who are caught smoking can usually be detected by the smell when talking. Usually students smoke in congregation means that one cigarette is smoked by several students .

Recognize Something That Is Not His Right. There is an interesting finding in State Junior High School 25 that there are some students who perceive if they find goods or objects, then the item belongs to them, without having to inform or offer to others about the item. According to the understanding of these students the wrong thing is if stealing means taking something that belongs to someone else. This kind of thing is a habit that is brought from home and its social environment.

Absence School Without Permission. The maximum maximum limit for students can go up to class is $10 \%$ of effective days. This year an effective day is 190 days. So the maximum limit for being able to go up to class is 19 days, if you don't enter 20 days it means you can't go up to class. Here are many cases like this. There are $7 \mathrm{C}$ graders who have not entered as many as 28 days, even though the school is only a few months old. Once in t elisik this child turns out there is a problem family, his mother remarried, lived here with his father and often scolded. 
Dating. Not infrequently in this group of teenagers, middle school students are dating. Some SMP Negeri 25 students are dating both men and women. Some are dating school friends, there are also female students who are dating car washers. Sometimes students date in class when going home from school. Several times students were caught red-handed while dating in class. So if you go home from school picket teacher, security guard and BK teacher and Deputy headmaster usually go around watching the classes The violation of the sense of wedi (fear) in the form of saying dirty / disrespectful towards the teacher, mombolos, smoking, not going to school without permission, and dating as a lifestyle that is carried out by a small number of middle school students in North Semarang, meaning that in general students are still afraid do these forms of violation. Chane say that life depends on forms cultural respectively, is a style of manners, how to use the goods, place and time that is characteristic su at u group, but not their overall social experience[4]. Lifestyle is a set of practices and attitudes that make sense in certain contexts. The fading of the taste of wedi (fear) against offenses in the category of severe sanctions due to several factors, including family environment / socially students outside of school that supports not obey school rules, such as friends with children who are not school or other family members accustomed to drinking, drinking, using illegal drugs, so that the condition is internalized in students.

Shyness .Shyness is a more positive shame. In contrast to the taste of isin, the feeling of reluctance is not a feeling to be prevented. Hildred Geertz describes it as "polite respect for superiors or unknown" as a subtle restraint on one's own personality for the sake of respect for others. Shyness is a positive shame that is felt dealing with superiors The forms of reluctance found are Do Not Dare To Reprimand The Teacher Who Plays Cellphone And Overslept When Teaching

One of the rules in State Junior High School 25 is the prohibition of carrying mobile phones for students, if found, students bring HP will be subject to sanctions according to applicable rules. But sometimes there are teachers who are on the sidelines teaching while playing cellphones. In addition there is one teacher who has diabetes, so often these teachers fall asleep while teaching, because it is inherited from the disease which causes people to become often sleepy. Faced with this condition students do not dare to rebuke, because there is a feeling of reluctance, but often students are even crowded in class which sometimes disrupts other classes.

The reason for the feeling of reluctance is still sustainable in Javanese culture, among others, that Javanese people still have to respect older people or have a higher position. a sense of reluctance will naturally emerge, the feeling is a psychological mechanism and not the object of the demand for respectful orders. Whereas Ramadan said that Shirk is an emotion that is typical of Java [15]. Shyness is an unpleasant feeling of reluctance, as well as respect for others about something from within. . Shyness prevents people from doing inappropriate actions .

\section{Conclusion}

The existence of Javanese ethical values as a lifestyle among junior high school students in North Semarang has undergone a shift. Javanese ethics contains two principles, namely harmony and respect. The fading of harmonious values can be seen from the presence of fights between middle school students, both done individually and in groups in the form of brawls . While respectful values experience fading in the sense of isin (embarrassed) and wedi (afraid), while the feeling of reluctance still belongs to middle school students in North Semarang. 
The fading of the existence of Javanese ethical values as a lifestyle for a small number of junior high school students in North Semarang is caused by a variety of factors, including those from the family environment and social environment that are far from applying Javanese ethical values so that students have internalized behavior deviating from Javanese ethical values . 


\section{Reference}

[1] F. M. Suseno, Etika Jawa: Sebuah Analisa Falsafi tentang Kebijaksanaan Hidup Jawa. jakarta: Gramedia Pustaka Utama, 2001.

[2] C. Geertz, Tafsir Kebudayaan. Yogyakarta: Kanisius, 1992.

[3] A. Idi, Sosiologi Pendidikan Individu, Masyarakat, dan Pendidikan. jakarta: Rajawali Pers, 2011.

[4] D. Chaney, Lifestyle Sebuah Pengantar Komprehensif. Yogyakarta: Jalasutra, 2004.

[5] P. Gilbert and C. Irons, "Shame, self-criticism, and self-compassion in adolescence," in Adolescent Emotional Development and the Emergence of Depressive Disorders, N. B. Allen and L. B. Sheeber, Eds. Cambridge: Cambridge University Press, pp. 195-214.

[6] B. Suryanto, Sosiologi Ekonomi Kapitalisme dan Konsumsi di Era Masyarakat Post-Modern. jakarta: Kencana Prenada Media Group, 2013.

[7] A. Adlin, Resistensi Gaya Hidup : Teori dan Realitas. Yogyakarta: Jalasutra, 2006.

[8] S. R. Mathur and K. M. Corley, "Bringing ethics into the classroom: Making a case for frameworks, multiple perspectives and narrative sharing," Int. Educ. Stud., vol. 7, no. 9, pp. 136-147, 2014.

[9] N. Miloradova and A. Ishkov, "Environmental Ethics as a Social, Professional and Personal Value of the Students of Civil Engineering University," Procedia Eng., vol. 117, pp. 246-251, 2015.

[10] K. Sanga, "Fānanaua,” Int. J. Crit. Indig. Stud., vol. 8, no. 1, pp. 17-31, Jan. 2015.

[11] T. Trianton, "ETHICS VALUES AS THE PORTRAYAL OF BANYUMAS LOCAL WISDOMS IN THE NOVELS OF AHMAD TOHARI," Int. J. Lang. Educ., vol. 1, no. Volume 4 Issue 3, pp. 306-306, Jan. 2016.

[12] A. Mohammadpur and K. Mahmoodi, "Lifestyle and identity in contemporary Iranian Kurdistan (a grounded study of Marivan City)," Qual. Quant., vol. 50, no. 5, pp. 1907-1928, Sep. 2016.

[13] J. E. Chukwuere, "The Impact Of Social Media On Social Lifestyle: A Case Study Of University Female Students," pp. 10251-10267, 2017.

[14] Sugiyono, Metode Penelitian Pendidikan: Pendekatan Kuantitatif, Kualitatif dan R\&D. Bandung: AlfaBeta, 2019.

[15] R. Faizal, "Memaknai Budaya sungkan Emosi Khas dari Jawa Kompasiana," 2014. [Online]. Available: https://www.kompasiana.com/faizalramadhan39/54f964f0a3331150278b4c1e/memaknaibudaya-sungkan-emosi-khas-dari-jawa. 